\title{
The Cost of Shame: International Organizations and Foreign Aid in the Punishing of Human Rights Violators*
}

\author{
JAMES H. LEBOVIC \\ Department of Political Science, George Washington University
}

\section{ERIK VOETEN}

\author{
Edmund A. Walsh School of Foreign Service and Department of Government, \\ Georgetown University
}

\begin{abstract}
Are violators of international human rights norms punished with lower levels of foreign aid? Despite their abstract preferences, governments often lack the incentive to punish norm violators bilaterally. Multilateral lending institutions, such as the World Bank, could fill the void if they wanted to consider human rights abuses and could bypass restrictions on evaluating the political character of recipients. This article argues that 'shaming' in the United Nations Commission on Human Rights, through resolutions that explicitly criticized governments for their human rights records, provided substantive information about rights abuses and gave political cover for the World Bank and other liberal multilateral aid institutions seeking to sanction human rights violators. Statistical analyses support these theoretical claims. The adoption of a UNCHR resolution condemning a country's human rights record produced a sizeable reduction in multilateral, and especially World Bank, aid but had no effect on the country's aggregate bilateral aid receipts. The analyses also support predictions that 'objective' measures of human rights have no independent effect on multilateral aid allocations. The findings, which are robust to different model techniques and specifications, suggest that punishment for violating international human rights norms is selective, that international organizations play an important role in the selection process and, thus, that seemingly symbolic resolutions of a politically motivated IO can carry tangible consequences.
\end{abstract}

\section{Introduction}

How and when does the international community punish violators of international human rights norms? Certainly, deposed rulers and their accomplices must account, at

\footnotetext{
* We wish to thank Emilie Hafner-Burton, Steven Poe, James Ron, and three anonymous referees for their useful comments. The data and appendix containing robustness tests are available at http://www.prio.no/jpr/datasets. The authors can be reached at lebovic@gwu.edu or ev42@ georgetown.edu.
}

times, for their barbarous conduct in office. This is apparent in the prosecution of Saddam Hussein in Iraq, Slobodan Milosovic in the former Yugoslavia, and other alleged war criminals by international or hybrid tribunals. There is little evidence, however, that mechanisms are in place to hold governments accountable routinely and consistently for ongoing violations and to give violators reasons to improve their records. Global international human rights treaties lack teeth and rely upon weak normative pressures for 
enforcement (see Hafner-Burton \& Tsutsui, $2005,2007)$. Governments do not appear to receive substantial material benefits, such as economic assistance, for adhering to rights norms, or experience costs in lost benefits for violating them. Research suggests that the strategic relationship between a donor and recipient and, to a lesser extent, the economic needs of the recipient account for the flow of aid and that human rights abuses are a modest, negative predictor of bilateral allocations for only some donor countries (Alesina \& Dollar, 2000; Alesina \& Weder, 2002; Lebovic, 1988, 2005; Neumayer, 2003a).

Existing findings pertain only to a direct relationship between assistance and rights practices. Yet, states might punish human rights violators indirectly by passing the task to international organizations (IOs) that are not under pressure to preserve strategic relationships with rights abusers. This is a possible result if: (1) multilateral aid institutions want to consider these abuses, and (2) multilateral aid institutions can bypass restrictions on evaluating the political character of potential recipients. We speculate that both conditions apply. Specifically, we argue that a multilateral aid institution might selectively reduce aid when receiving signals from the international community that certain human rights violators are politically acceptable targets. Such signals are provided by public votes in IOs, in this case the United Nations Commission on Human Rights (UNCHR). 'Shaming' in the UNCHR through resolutions that explicitly criticized a government for its human rights record provided substantive information about rights abuses and gave political cover for liberal multilateral aid institutions seeking to sanction human rights violators. The result was a reduction in multilateral - but not bilateral - aid received by targets of public UNCHR resolutions.
Admittedly, we invite controversy by arguing that multilateral aid-granting institutions that promote the policy preferences of Western industrial states take guidance from an institution, like the UNCHR, that was notorious for its biased handling of rights abuses throughout the Cold War and post-Cold War periods. The UNCHR was formally disbanded in 2006 after a decadeslong history that provoked charges that members were more interested in protecting themselves and their allies and hurting enemies than in punishing rights abuses. Our response is twofold. First, we concede that politics influenced commission behavior; in fact, our argument requires a widely held perception that UNCHR resolutions were politically motivated (i.e. some abusers avoided punishment and other states received relatively severe sanctions, at least partially for political reasons). We also assume, however, that some states - Burma, South Africa under a white minority government, Cambodia under Pol Pot, and Iraq under Saddam Hussein, to name but a few became political outcasts within the international community in no small measure because these states were abusive. The targeting by the commission of these states signaled effectively that they were 'safe targets' for material and non-material sanctions by other institutions, dispatched at their discretion. An earlier study (Lebovic \& Voeten, 2006) substantiates the assumptions that UNCHR resolutions were motivated by both political factors and actual human rights violations. Second, we do not assume that donor institutions methodically monitored the actions of the UNCHR or that its resolutions were important in a formal or legalistic sense. We assume only that these resolutions articulate global political realities that are gleaned, as well, from other (perhaps less formal) international sources. We remain open to the possibility, however, that these 
resolutions damaged the reputations of the targeted countries and increased their susceptibility to punishment.

In this article, we focus on two IOs - the UNCHR, the UN's main body for sanctioning countries for their human rights abuses, until it was replaced by the Human Rights Council in 2006, and the World Bank Group (in particular, the International Bank for Reconstruction and Development, or IBRD, and the International Development Association, IDA). In principle, our theory applies to all international financial institutions that might take domestic human rights violations into account but are politically constrained from doing so. We focus on the World Bank because it is the largest global multilateral aid institution devoted to development aid, a liberal institution (given weighted voting that favors Western, industrialized countries), and attentive to human rights and legal institutions within participating countries, compared with other global international financial institutions such as the International Monetary Fund. Indeed, the World Bank is under increasing pressure to consider the political character of recipient governments despite explicit prohibitions from doing so in the Bank's Articles of Agreement (founding document).

We organize this article as follows. First, we present the theory behind our arguments and the plausible roles of the World Bank and the UNCHR in punishing rights abuses. Second, we present descriptive evidence for our main hypotheses using cross-sectional time-series data on aggregate bilateral, multilateral, and World Bank aid commitments from 1979 to 2002. During this period, the UNCHR became increasingly active and employed diverse mechanisms to sanction a wide variety of countries. Third, we subject our hypotheses to rigorous tests with multiple regression analysis. Fourth, we conduct robustness tests of our results, including a replication of an earlier study (Neumayer, 2003b). We conclude that the support for our propositions is considerable and robust with respect to alternative model specifications and estimating techniques. The evidence supports prior findings that 'objective' measures of human rights have no robust effect on aid allocation and shows further that UNCHR resolutions have no impact on aggregate bilateral aid. The evidence establishes, however, that these resolutions have a substantial effect on multilateral aid and World Bank aid.

\section{Human Rights Norms, Aid Giving, and IOs}

Evidence abounds that governments internalize human rights norms by incorporating them into their own domestic rights practices (e.g. Risse \& Sikkink, 1999). Yet, the social stigma of violating human rights norms is obviously insufficient to prevent widespread rights abuses, and many governments sign and ratify human rights treaties and then routinely violate them (e.g. Hathaway, 2002). Therefore, it is helpful to study the mechanisms that states employ to reward compliance and sanction non-compliance with given rights standards, as well as the obstacles that impede the effective use of these mechanisms.

One plausible mechanism, in this regard, is bilateral aid. Scholars have long studied the extent to which donor countries condition their aid allocations on the human rights and democratic practices of potential recipients. Most empirical studies on the subject focus on US foreign aid (e.g. Abrams \& Lewis, 1993; Apodaca \& Stohl, 1999; Carleton \& Stohl, 1987; Cingranelli \& Pasquarello, 1985; Meernik, Krueger \& Poe, 1998; Poe, 1992), with mixed results. In general, they reveal that aid is more sensitive to a country's political and civil liberties than personal integrity rights and that economic aid, more 
than military aid, is influenced by rights considerations. The significance of these effects is not robust, though, to method, period, and location. Studies on a broad range of donors also indicate that despite their selfproclaimed commitment to human rights, aid allocations are largely based on the political objectives of donors and, less so, on the economic needs of recipients and/or their rights practices (e.g. Alesina and Dollar, 2000; Carey, 2007; Lebovic, 1988, 2005; Neumayer, 2003c,d; Schraeder, Hook \& Taylor, 1998). ${ }^{1}$ It appears, then, that aid is used to reward countries for their economic (e.g. trade), historical (e.g. colonial ties), political (e.g. UN voting), and military relevance (e.g. security ties) to the donor, rather than to reward or punish these countries for their domestic human rights performances.

These findings do not necessarily imply that donor governments are indifferent to the human rights practices of aid recipients. Instead, a weak relationship (at best) between human rights indicators and governmental aid flows might simply reflect the difficulties of implementing bilateral punishment strategies. If bilateral aid to a country serves strategic purposes, then donor governments prefer some other government or institution to punish that country for its human rights violations. Doing otherwise could result in lost opportunities to sustain or build a relationship with an important country and competitive disadvantages relative to other donors that are willing to aid the violator to claim a valuable market, raw material source, or military prize, such as a base or port (Lebovic, 2005). Thus, donor governments might hide behind the policies and procedures of (somewhat non-transparent) international institutions by allowing them to perform a 'laundering' function (e.g. Abbott $\&$ Snidal, 1998).

${ }^{1}$ Human rights records are more important aid-granting criteria for some smaller (mostly Scandinavian) countries.
These institutional deference strategies are impaired, however, by the limited mandates of multilateral aid organizations. The World Bank's Articles of Agreement, for example, forbid interference in the political affairs of its members and consideration of the 'political character' of recipient governments. Public challenges to this posture incite fierce resistance. A case in point is the 2006 decision by the executive board of the Bank to oversee its corruption policy, after then-President Paul Wolfowitz admitted publicly that he had withheld more than $\$ 1$ billion in aid to countries on suspicions of corruption (Torchia, 2006). As one board member retorted, 'the bank should not become a world policeman pointing its moral finger and conditioning everything on whether or not a country is believed to be corrupt. The more the bank goes beyond its old mandate of reducing poverty, the more problems will come up' (quoted in Weisman, 2006). This obviously uncompromising response is rooted in realistic fears that an anti-corruption campaign will lead to growing Bank intrusions into politics within aid-recipient countries. Indeed, Wolfowitz (2006) linked the fight against corruption to the building of 'transparent and accountable institutions' - and these, in turn, to democracy-building (e.g. a free press and independent judiciary) within candidate countries. Still, the overall reaction within the Bank speaks more to Wolfowitz's stylistic affront to World Bank practices, and a general wariness about Wolfowitz's motives, than to an institutional aversion to considering a country's political practices when dispersing aid. Wolfowitz was tainted by his lingering association with the (unilateralist and unpopular global policies of the) Bush administration, and he only increased internal suspicions with his selective accusations of corruption that appeared to target countries on the outs with the administration. Wolfowitz's offense was apparently that his actions were public and (at best) 
ad hoc - that he broke a consensual norm in decisionmaking, failed to live by established and transparent criteria, and, in consequence, alienated potential state supporters within the Bank, including traditional US allies. ${ }^{2}$ The reality is that political criteria are politically sensitive, by definition, and preferably introduced into funding decisions with caution to avoid opening the Bank to charges of bias. Participants must feel comfortable that the targeted countries are worthy of punishment and that the use of political criteria will not set precedents that politicize - and maybe paralyze - the institution.

In practice, political considerations - and human rights, in particular - had come to shape the World Bank's aid granting criteria well before Wolfowitz's appointment (see Bradlow, 1996; Saiegh, 2005; Skogly, 2001), for the following reasons. ${ }^{3}$ First, the Bank staff, which has considerable power in recommending projects, has acted within the leeway allowed by an absence of clear guidelines on what constitutes the 'economic' and the 'political'. Second, the World Bank has assessed how its programs and policies affect societies, cultures, minorities, and genders, with an expansion in the number of global treaties that govern the rights of these groups and concerted efforts by nongovernmental organizations (NGOs) to push their agendas upon intergovernmental institutions. The refocusing has been institutionalized through the installation of specific Bank divisions that address these matters. Third, the World Bank's economists have recognized that the economic aspects of policies, programs, and projects cannot be considered apart from their political dimensions. ${ }^{4}$ For example, in

\footnotetext{
${ }^{2}$ For a good discussion of Wolfowitz's controversial tenure at the World Bank, see Cassidy (2007).

${ }^{3}$ An extended discussion is found in Bradlow (1996).

${ }^{4}$ This represents a shift in thinking in the economics profession more generally toward considering a country's human capital and legal and political institutions as essential for economic growth (e.g. Becker, 1994; North, 1990).
}

1998 the World Bank published an influential Policy Research Report, which argued that aid has been effective only in countries with 'good governance' (World Bank, 1998). Consequentially, the Bank has increased its efforts to measure good governance and now publishes rankings of its aid recipients on various aspects of good governance, ${ }^{5}$ including human rights (see Kaufmann, 2005).

Whereas the Bank focused traditionally on infrastructure, it now devotes more than half of its lending to human development and legal and institutional reforms. The expected return depends critically upon the domestic political and social character of a country. Important, too, is that the Bank has increased its collaboration with the UN High Commissioner for Human Rights, ${ }^{6}$ which led to the formation of a Work Group on Human Rights headed by general counsel Roberto Dañino. He argued that changing legal understandings of the protections of sovereignty and changing beliefs about the relation between human rights and economic development require a broader interpretation of the limits imposed by the Bank's Articles of Agreement (Dañino, 2004). ${ }^{7}$

Although the World Bank has allegedly denied aid to countries like Kenya and Malawi specifically because of their rights practices (though justifying the decision in economic terms; see Bradlow, 1996: 79), the Bank must be sensitive to political constraints. We suggest that UNCHR resolutions that publicly chastised countries for their human rights abuses provided relevant signals to the Bank staff. These resolutions conveyed information about human rights violations and the political opposition to the

\footnotetext{
5 The World Bank's governance data can be accessed at: www.worldbank.org/wbi/governance/data.

6 For example, see Note from the President to the 71st Meeting of the Development Committee, 12 April 2005.

${ }^{7}$ Notably, Dañino singled out the International Covenant on Civil and Political Rights, the primary rights treaty that the UNCHR seeks to enforce.
} 
abusers within the international community. Thus, we suggest that UNCHR resolutions were informative - not despite, but, at least partially, because of the politics involved in commission decisions. ${ }^{8}$

The UNCHR served for over half a century as the principal UN organ for promoting global respect for human rights, with a mandate to scrutinize rights practices and enforce an ever-growing number of rights treaties. (For a detailed look at the UNCHR and its performance, see Lebovic \& Voeten, 2006.) Each spring, more than 3,000 delegates from governments and NGOs congregated in Geneva to attend the commission's six-week regular session. With the diverse membership of the commission, its deliberations and sanctioning votes were often controversial, and certainly political. Given profound differences in outlook and interests among its members, the commission focused on principle throughout much of its early history and confined its specific efforts to symbolic cases - notably, Israel, South Africa, and Chile. This led Donnelly (1988) to conclude that the commission was biased against pro-US and in favor of left-leaning regimes. By the 1980s, the commission had acquired several devices, of varying severity, for expressing displeasure with a country's rights practices and, by the end of the Cold War, the commission was liberally employing all of these instruments. The UNCHR held hearings, appointed investigators, and with its most powerful tool, passed public resolutions that officially, loudly, and unequivocally condemned a large variety of countries for their purported abuses. During our period of analysis, the UNCHR examined the human rights records of 92 countries at least once, reprimanded 62 countries at least once, and adopted public resolutions criticizing the human rights records of 34 different countries, many on multiple occasions.

Through these resolutions, the commission continued to engage in selective sanctioning votes that included the frequent targeting of Israel to the neglect of major rights abusers such as China. Indeed, concerns about questionable voting and the human rights records of some of the UNCHR's members led the UN Secretary General to call for disbanding the commission, resulting in negotiations for a replacement body, which culminated in the creation of the Human Rights Council in June 2006. Nevertheless, politics was not the only source of commission behavior even in the Cold War years. In a large statistical analysis, Lebovic \& Voeten (2006) conclude that politics mattered in targeting and punishment by the UNCHR but so did increasingly a variety of other factors that do not fit comfortably with a realist account. These factors include whether potential targets have committed formally to major rights treaties, the rights practices of these countries, and their participation within the international community (i.e. various IOs).

Thus, multilateral aid organizations might have looked to the UNCHR to identify rights abusers that were punishable with impunity. We assume that the World Bank was peculiarly attentive to the international standing of a country with respect to its human rights practices, given the Bank's well-documented liberal bias, attention to the domestic practices of recipient governments, and desire to avoid contentious decisions. ${ }^{9}$ At the same time, we do not believe that the World Bank or other multilateral institutions distributed aid in response to the more impartial rights assessments of

\footnotetext{
8 For a similar argument regarding the UN Security Council, see Voeten (2005).
} 
NGOs, such as Amnesty International. If our arguments hold, such judgments affected aid receipts indirectly by helping shape a political consensus that certain violators deserve punishment. We thus test the following hypotheses:

H1: Countries publicly sanctioned by the UNCHR experience reduced multilateral aid allocations, especially World Bank loans.

H2: Countries publicly sanctioned by the UNCHR do not experience reduced bilateral aid allocations.

H3: Assessments of human rights violations have no direct effect on multilateral aid allocations.

Theoretically, this argument fits most comfortably within the liberal institutionalist framework (Keohane \& Martin, 1995). It suggests that IOs help governments address two dilemmas - the first, a coordinative dilemma and, the second, a collaborative one. With respect to coordination, political institutions render judgments that serve as a focal point, that is, widely accepted opinions that a transgression should be punished (Weingast, 1997; Voeten, 2005). With respect to collaboration, IOs (multilateral aid institutions) help governments cooperate when they have strong incentives to defect.

\section{Shaming and Aid: Preliminary Patterns}

The OECD's International Development Statistics is the source for our aid data. ${ }^{10}$ Our main dependent variables are total official development aid (ODA), commitments from OECD countries (bilateral aid), multilateral institutions (including World Bank), and the World Bank (IDA and IBRD), in

\footnotetext{
${ }^{10}$ http://www.oecd.org/dac/stats/idsonline.
}

2004 US dollars. We focus on commitments because these are tied most proximately to decisions by governments and IOs to reward or punish the actions of governments. ${ }^{11}$

The sample includes all countries identified as 'developing countries' by the OECD in the 1979-2002 period. ${ }^{12}$ As is common in studies of aid allocation, we exclude Egypt and Israel from the analysis to acknowledge the unique aid trajectory and amounts for these countries. This leaves us with 118 developing countries. Our main independent variable is the adoption of a public UNCHR resolution. We expect that a UNCHR resolution in year $t-1$ will produce a drop in aid the next year. Thus, we collect data on public UNCHR resolutions from 1978-2001. In this period, UNCHR adopted resolutions targeting 31 different developing countries.

Figure 1 plots the average commitment of aid (per capita) to countries that were and were not condemned by a public UNCHR resolution in the preceding year. The graphs show that, on average, developing countries subject to a UNCHR resolution received less than half the World Bank commitments of countries that were not accorded this treatment. Similarly, total multilateral ODA commitments were almost half those for countries subjected to UNCHR shaming. There was no notable difference, however, in the bilateral aid commitments received by countries that were, and were not, singled out by the UNCHR.

This evidence is only suggestive and does not control for several confounding factors. For that reason, we turn to the estimation of multiple regression models.

\footnotetext{
11 An alternative, net aggregate ODA, includes large numbers of negative values for World Bank ODA, in particular, because of adjustments for interest or other loan payments. Gross aid allocations presumably include amounts in the pipeline prior to UNCHR action.

12 The year, 1978, is the first for which data on public UNCHR resolutions are available.
} 
Figure 1. Bilateral and Multilateral Aid Per Capita for Developing Countries With and Without a Public UNCHR Resolution

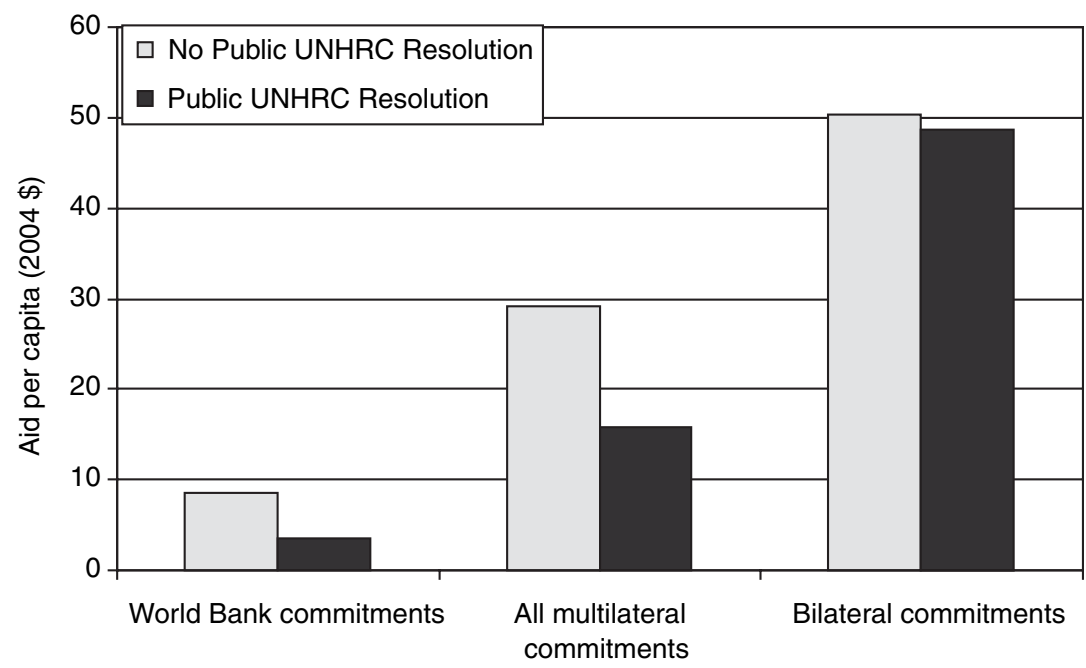

\section{Multiple Regression Analysis}

In this section, we present the control variables for our multiple regression analysis, the statistical model that we estimate, and the resulting model estimates. Table I presents the descriptive statistics for all variables included in the analysis for both the full sample of 115 developing countries and the 84 countries that received aid from the World Bank (IDA or IBRD) within the assessed time frame. We use natural log transformations for all variables measured in dollars as well as population to facilitate the estimation of linear models and to make the results more robust to outliers. Our hypotheses tests are uninfluenced, however, by these transformations.

\section{Control Variables}

The effects of UNCHR resolutions on aid could easily be conflated with the effects of the human rights performance for a given country and year, as judged by a more impartial source. Because human rights performance can affect both the probability of a UNCHR resolution and aid levels, our models include the widely used 'Political Terror Scale' (PTS) based on Amnesty International reports. ${ }^{13}$ Countries are ranked for their physical integrity rights on a fivepoint scale, where countries with low values exhibit little or no political terror and countries with high values experience regular terror and abuse. We also include Freedom House civil liberty scores in our model. ${ }^{14}$ Freedom House yearly assigns scores to countries on a seven-point scale, where low scores (1) indicate the most free countries and high scores (7) the least free countries. These two indicators measure quite distinct

13 For information on the data, see Gibney \& Dalton (1996). The data were acquired from http://www.unca.edu/politicalscience/images/Colloquium /faculty-staff/gibney.html (accessed 18 September 2007). Although we used the PTS data derived from Amnesty International reports, we imputed missing values from PTS values based on State Department reports, GNP, an indicator for a left executive, and level of democracy (Polity score). (These methods are described in Lebovic \& Voeten, 2006: 873-874.) An experiment that leaves 100 actual observed values out of the imputation indicates that the imputation performs very well (the correlation between actual and imputed values exceeds .9).

14 These scores are available at http://www.freedomhouse.org. 
Table I. Descriptive Statistics

\begin{tabular}{|c|c|c|c|c|}
\hline & \multicolumn{2}{|c|}{ Full sample } & \multicolumn{2}{|c|}{ Only World Bank countries } \\
\hline & UNCHR & No UNCHR & UNCHR & No UNCHR \\
\hline Ln(bilateral aid per capita) & $\begin{array}{c}2.83 \\
(1.61)\end{array}$ & $\begin{array}{c}3.08 \\
(1.23)\end{array}$ & $\begin{array}{c}3.18 \\
(1.11)\end{array}$ & $\begin{array}{c}3.35 \\
(1.03)\end{array}$ \\
\hline Ln(multilateral aid per capita) & $\begin{array}{c}1.73 \\
(1.46)\end{array}$ & $\begin{array}{c}2.38 \\
(1.39)\end{array}$ & $\begin{array}{c}2.27 \\
(1.44)\end{array}$ & $\begin{array}{c}2.74 \\
(1.27)\end{array}$ \\
\hline Ln(World Bank aid per capita) & - & - & $\begin{array}{c}0.47 \\
(1.01)\end{array}$ & $\begin{array}{c}1.23 \\
(1.31)\end{array}$ \\
\hline $\operatorname{Ln}($ GDP per capita) & $\begin{array}{c}6.68 \\
(1.15)\end{array}$ & $\begin{array}{c}6.75 \\
(1.20)\end{array}$ & $\begin{array}{c}6.50 \\
(0.92)\end{array}$ & $\begin{array}{c}6.26 \\
(0.82)\end{array}$ \\
\hline $\operatorname{Ln}$ (population) & $\begin{array}{l}16.09 \\
(1.52)\end{array}$ & $\begin{array}{l}15.84 \\
(1.60)\end{array}$ & $\begin{array}{c}15.68 \\
(1.55)\end{array}$ & $\begin{array}{l}16.00 \\
(1.59)\end{array}$ \\
\hline PTS (1-5 scale) & $\begin{array}{c}3.88 \\
(1.11)\end{array}$ & $\begin{array}{c}2.72 \\
(1.04)\end{array}$ & $\begin{array}{c}3.80 \\
(1.10)\end{array}$ & $\begin{array}{c}2.78 \\
(1.00)\end{array}$ \\
\hline Civil liberties (7-point scale) & $\begin{array}{c}5.32 \\
(1.41)\end{array}$ & $\begin{array}{c}4.62 \\
(1.49)\end{array}$ & $\begin{array}{c}5.33 \\
(1.22)\end{array}$ & $\begin{array}{c}4.66 \\
(1.43)\end{array}$ \\
\hline Agreement with USA & $\begin{array}{c}0.37 \\
(0.15)\end{array}$ & $\begin{array}{c}0.35 \\
(0.12)\end{array}$ & $\begin{array}{c}0.37 \\
(0.12)\end{array}$ & $\begin{array}{c}0.35 \\
(0.12)\end{array}$ \\
\hline War & $\begin{array}{c}0.60 \\
(0.49)\end{array}$ & $\begin{array}{c}0.25 \\
(0.43)\end{array}$ & $\begin{array}{c}0.47 \\
(0.50)\end{array}$ & $\begin{array}{c}0.27 \\
(0.44)\end{array}$ \\
\hline Capabilities & $\begin{array}{c}0.02 \\
(0.02)\end{array}$ & $\begin{array}{c}0.02 \\
(0.08)\end{array}$ & $\begin{array}{c}0.01 \\
(0.01)\end{array}$ & $\begin{array}{c}0.03 \\
(0.09)\end{array}$ \\
\hline $\mathrm{N}$ & 156 & 2,168 & 95 & 1,453 \\
\hline
\end{tabular}

Entries are mean values; standard deviations in parentheses.

aspects of a country's human rights record, both theoretically and empirically, as indicated by the relatively modest .21 bivariate correlation between these variables for our sample. As Table I shows, countries subject to UNCHR resolutions had somewhat worse human rights records than countries that were not subject to such resolutions in a given year.

Because the literature suggests that aid levels are need-based and because poorer countries might be inviting targets for UNCHR resolutions, we control for a potential spurious relationship by incorporating into the model a measure of economic need - the natural log of GDP per capita in 2004 dollars, drawn from International Development Statistics. A similar logic informs our decision to include population in our model. Given a potential bias against countries with large populations in per capita aid distribution (e.g. India receives large amounts of aid but not in proportion to its large population) and a plausible bias (for or against) large countries in the UN sanctioning process, we include the natural log of total population in the model.

As is common in the literature, we include a measure of vote correspondence with the United States in the UN General Assembly (e.g. Alesina \& Dollar, 2000; Andersen, Hansen \& Markussen, 2006). ${ }^{15}$ This variable measures how much a country's foreign policy orientation coincides with that of the United States and, indirectly, Western

\footnotetext{
15 We compute the Lijphart (1963) index of agreement based on valid votes only, where a 1 is given if a country votes with the USA, a 0 if the opposite, a 0.5 if one of the countries abstains and the other votes yes or no. If countries do not vote in a given year, a country-specific meanbased interpolation is used (based on the mean of values closest to the missing data-point).
} 
countries more generally (see Voeten, 2000). This variable is a useful control because Western countries, as influential participants in the World Bank and other large multilateral aid organizations, might promote their alignments with multilateral aid and because UN voting is a known correlate of UNCHR sanctioning behavior (Lebovic \& Voeten, 2006).

In addition, we include two control variables measuring the strategic standing of potential recipients. First, involvement in armed conflict may make a country more susceptible to UNCHR condemnation (as shown in Table I) and may reduce the country's supply of aid, at least from multilateral sources. Multilateral institutions generally distribute aid for specific projects which are less likely to succeed in countries that are actively involved in armed conflict either internally or externally (as resources are diverted toward the military, economic disruptions occur, infrastructures suffer, and populations are dislocated). We therefore include a dummy variable that takes the value 1 if a state is involved in an armed conflict, as identified by Gleditsch et al. (2002). ${ }^{16}$ Second, we include a measure of a country's material capabilities - based on the Correlates of War's Composite Indicator of National Capability (CINC). ${ }^{17}$ This is a composite indicator of military expenditure, military personnel, energy consumption, iron and steel production, urban population, and total population. If aid is determined by strategic concerns, we would expect that stronger countries receive more aid; moreover, if UNCHR shaming is political, we expect that, compared to weaker states, powerful states are more likely to escape UNCHR resolutions (see Lebovic \& Voeten, 2006).

\footnotetext{
16 They identify four types of conflict, which we aggregate here, but the results do not differ substantially if we separate internal and external wars.

17 Capabilities data were obtained from http://eugenesoftware.org, as described in Bennett \& Stam (2000).
}

Finally, we include orthogonal quadratic temporal trends. This controls for acrossthe-board fluctuations in levels of aid-giving. ${ }^{18}$

\section{Methods}

In our main specification, the dependent variable is the natural log of aid per capita, as is common in the literature (e.g. Alesina $\&$ Weder, 2002). ${ }^{19}$ The model includes a lagged dependent variable to account for the general stability in aid receipts. All covariates are entered with one-year lags. Human rights violations are also included as first differences to account for short-term changes in human rights observance that might have an immediate effect on aid (see Neumayer, 2003d). ${ }^{20}$

An important decision in any analysis of time-series cross-section data concerns the amount of pooling to assume across units (countries). Traditionally, the choice has been to either assume full pooling (all countries are homogenous) or no pooling (a specific intercept for each country or 'fixed effects'). We estimate fixed effects models but follow recent developments in the literature by also estimating a random effects model that allows for unit (country) heterogeneity but is not as restrictive as the fixed effects model. ${ }^{21}$ This model can be estimated through full MLE and offers considerable advantages over alternative pooling assumptions (see Beck \& Katz, 2007). ${ }^{22}$ We include

18 Specifically, we use Hermite polynomials; see http://mathworld.wolfram.com/HermitePolynomial.html. A third degree polynomial was insignificant in the models.

${ }^{19}$ More precisely, in order to account for zero values, $\ln$ (aid commitments per capita +1 ).

${ }^{20}$ Results when the other variables are first-differenced are available from the authors.

${ }^{21}$ Fixed effects are especially problematic given that we already have a lagged dependent variable and our N (crosssection) is considerably larger than our $\mathrm{T}$ (time-series). Moreover, a Hausman test provides no evidence to support fixed effects.

${ }^{22}$ Beck \& Katz note that the more traditional FGLS estimator for random effects models has poor properties in finite samples, so we use their recommended MLE estimator. An alternative is to use a Bayesian approach using Gibbs or Metropolis-Hastings sampling (e.g. Western, 1998). 
the measures for human rights abuses both as levels and changes, acknowledging the possibility that short-term positive (negative) shifts in levels of human rights abuses may lead to rewards (punishments). With covariates $\mathrm{X}$, treatment variable $\mathrm{T}$ (in deference to the special 'treatment' accorded some countries via a UNCHR resolution), ${ }^{23}$ and country-specific normally distributed random effects $Z$, the main regression equation is:

$$
\begin{aligned}
\operatorname{AidCap}_{j, t}= & \beta_{0}+\beta_{1} \operatorname{AidCap}_{j t-1}+\beta_{2} \mathrm{X}_{j t-1} \\
& +\beta_{3} \Delta \mathrm{X}_{j, t}+\beta_{4} T_{j, t-1}+Z_{j}+U_{j, t}
\end{aligned}
$$

\section{Results}

Table II presents the results of the random and fixed effects regressions. Although our hypotheses are directional, we perform more conservative two-tailed hypothesis tests (though the results of one-tailed tests are easily inferred from the reported $z$ - and $t$ values). A number of conclusions emerge.

First, there is virtually no evidence in the models that the human rights record of a country directly affects its aid receipts. The coefficients on both the level of, and changes in, domestic physical integrity rights are negatively signed, as expected, in most regressions. Yet, only short-term changes in physical rights abuses reach conventional levels of statistical significance, and only in the analysis of bilateral aid receipts. (Similar results are obtained from models that employ only one of the two rights indicators.) As with previous analyses, we detect no consistent evidence, then, that human rights abuses consistently affect aid receipts and no evidence that human rights abuses influence multilateral aid receipts. Simply put, it appears that violations generally go unpunished. This

23 Conceiving of the sanctioning of a country by the UNCHR as a 'treatment' also provides a conceptual link to the Heckman treatment models used in subsequent robustness tests. result is consistent with prior findings in the literature.

Second, public UNCHR resolutions do not have a significant negative impact on overall bilateral aid commitments. This also holds when we analyze only US aid disbursements. ${ }^{24}$ Nevertheless, public UNCHR resolutions significantly - and greatly - affect World Bank aid and multilateral aid. The results from the random effects model imply that a UNCHR resolution is associated with an average per capita reduction in multilateral aid of $35 \%$, holding other variables at their means and modes. The linkage between UNCHR resolutions and World Bank aid is even greater - a resolution is tied to a $52 \%$ reduction in average per capita World Bank commitments. The fixed effects estimates are somewhat smaller, suggesting a $32 \%$ reduction in aid per capita from both the World Bank and all multilateral sources. Together, these findings provide strong support for our hypotheses. It appears that a negative UNCHR resolution is associated with a drop by roughly one-third in overall multilateral and World Bank aid, but not in bilateral aid.

The results for the other variables in the model also deserve recognition. Supporting prior research, these indicate that aid receipts are stable (judging from the positive and significant endogenous lag-term coefficient), that poorer countries receive more aid per capita than wealthier countries (although note that this effect disappears in some fixed effects specifications), and that more-populated countries receive less aid than less-populated countries on a per capita basis. Also, participation in armed conflict is shown to have a significant negative effect on aid receipts, especially World Bank aid. Although there is little evidence that aid flows disproportionately to countries with superior material (military) capabilities,

${ }^{24}$ The results are in the web appendix. 
Table II. Random and Fixed Effects MLE Regressions on Logged Aid per Capita, 1979-2002

\begin{tabular}{|c|c|c|c|c|c|c|}
\hline & \multicolumn{2}{|c|}{ Bilateral } & \multicolumn{2}{|c|}{ All multilateral } & \multicolumn{2}{|c|}{ World Bank } \\
\hline & $R E$ & $F E$ & $R E$ & $F E$ & $R E$ & $F E$ \\
\hline Lagged dependent variable & $\begin{array}{c}0.553 \\
(25.51)^{* *}\end{array}$ & $\begin{array}{c}.448 \\
(16.58)^{* *}\end{array}$ & $\begin{array}{c}0.437 \\
(19.35)^{* *}\end{array}$ & $\begin{array}{c}0.328 \\
(11.31)^{* *}\end{array}$ & $\begin{array}{l}0.167 \\
(6.04)^{* *}\end{array}$ & $\begin{array}{l}-.089 \\
(2.49)^{*}\end{array}$ \\
\hline UNCHR Resolution & $\begin{array}{l}-0.03 \\
(0.51)\end{array}$ & $\begin{array}{l}-.064 \\
(1.03)\end{array}$ & $\begin{array}{l}-0.301 \\
(3.84)^{* *}\end{array}$ & $\begin{array}{l}-.280 \\
(3.04)^{* *}\end{array}$ & $\begin{array}{c}-0.423 \\
(3.02)^{* *}\end{array}$ & $\begin{array}{l}-.280 \\
(2.15)^{*}\end{array}$ \\
\hline$\Delta$ PTS & $\begin{array}{c}-0.037 \\
(2.20)^{*}\end{array}$ & $\begin{array}{l}-.039 \\
(2.37)^{*}\end{array}$ & $\begin{array}{c}0.016 \\
(0.71)\end{array}$ & $\begin{array}{c}.009 \\
(0.41)\end{array}$ & $\begin{array}{c}-0.018 \\
(0.46)\end{array}$ & $\begin{array}{l}-.025 \\
(0.63)\end{array}$ \\
\hline PTS $_{t-1}$ & $\begin{array}{c}-0.018 \\
(0.96)\end{array}$ & $\begin{array}{l}-.023 \\
(1.25)\end{array}$ & $\begin{array}{c}0.017 \\
(0.69)\end{array}$ & $\begin{array}{r}.007 \\
(0.29)\end{array}$ & $\begin{array}{c}-0.041 \\
(0.96)\end{array}$ & $\begin{array}{l}-.051 \\
(1.16)\end{array}$ \\
\hline$\Delta$ Civil liberties & $\begin{array}{c}-0.015 \\
(0.80)\end{array}$ & $\begin{array}{l}-.007 \\
(0.04)\end{array}$ & $\begin{array}{c}0.003 \\
(0.10)\end{array}$ & $\begin{array}{c}.008 \\
(0.31)\end{array}$ & $\begin{array}{c}0.004 \\
(0.08)\end{array}$ & $\begin{array}{c}.002 \\
(0.05)\end{array}$ \\
\hline Civil liberties $_{t-1}$ & $\begin{array}{c}-0.02 \\
(1.6)\end{array}$ & $\begin{array}{l}-.008 \\
(0.55)\end{array}$ & $\begin{array}{l}-.019 \\
(1.17)\end{array}$ & $\begin{array}{l}-.011 \\
(0.55)\end{array}$ & $\begin{array}{c}0.042 \\
(1.49)\end{array}$ & $\begin{array}{c}0.032 \\
(.09)\end{array}$ \\
\hline $\operatorname{Ln}\left(\right.$ GDP per capita $\left.t_{t-1}\right)$ & $\begin{array}{c}-0.107 \\
(4.26)^{* *}\end{array}$ & $\begin{array}{l}-.051 \\
(1.29)\end{array}$ & $\begin{array}{l}-0.33 \\
(11.72)^{* *}\end{array}$ & $\begin{array}{l}-.196 \\
(3.30)^{* *}\end{array}$ & $\begin{array}{c}-0.475 \\
(7.69)^{* *}\end{array}$ & $\begin{array}{l}-.270 \\
(2.80)^{* *}\end{array}$ \\
\hline $\operatorname{Ln}\left(\right.$ population $\left._{t-1}\right)$ & $\begin{array}{l}-0.162 \\
(5.23)^{* *}\end{array}$ & $\begin{array}{l}-.873 \\
(4.09)^{* *}\end{array}$ & $\begin{array}{l}-0.298 \\
(9.73)^{* *}\end{array}$ & $\begin{array}{l}-1.18 \\
(3.88)^{* *}\end{array}$ & $\begin{array}{c}-0.089 \\
(1.85)\end{array}$ & $\begin{array}{c}.192 \\
(0.33)\end{array}$ \\
\hline Agreement with USA ${ }_{t-1}$ & $\begin{array}{c}-0.123 \\
(0.85)\end{array}$ & $\begin{array}{l}-.328 \\
(2.13)^{*}\end{array}$ & $\begin{array}{c}0.261 \\
(1.36)\end{array}$ & $\begin{array}{r}.307 \\
(1.30)\end{array}$ & $\begin{array}{c}1.11 \\
(3.25)^{* *}\end{array}$ & $\begin{array}{r}.521 \\
(1.44)\end{array}$ \\
\hline War & $\begin{array}{c}-0.088 \\
(2.54)^{*}\end{array}$ & $\begin{array}{l}-.103 \\
(3.07)^{* *}\end{array}$ & $\begin{array}{l}-.110 \\
(2.38)^{*}\end{array}$ & $\begin{array}{l}-.110 \\
(2.33)^{*}\end{array}$ & $\begin{array}{c}-0.219 \\
(2.77)^{* *}\end{array}$ & $\begin{array}{l}-.212 \\
(2.60)^{* *}\end{array}$ \\
\hline Capabilities & $\begin{array}{c}-0.759 \\
(1.25)\end{array}$ & $\begin{array}{r}-1.59 \\
(0.85)\end{array}$ & $\begin{array}{c}0.096 \\
(0.17)\end{array}$ & $\begin{array}{c}2.518 \\
(1.50)\end{array}$ & $\begin{array}{c}-1.131 \\
(1.36)\end{array}$ & $\begin{array}{c}-3.13 \\
(1.56)\end{array}$ \\
\hline Time (1st spline) & $\begin{array}{c}-0.005 \\
(4.41)^{* *}\end{array}$ & $\begin{array}{r}.001 \\
(0.47)\end{array}$ & $\begin{array}{c}-0.003 \\
(1.89)\end{array}$ & $\begin{array}{c}.005 \\
(1.10)\end{array}$ & $\begin{array}{c}0.011 \\
(4.16)^{* *}\end{array}$ & $\begin{array}{c}.002 \\
(0.21)\end{array}$ \\
\hline Time (2nd spline) & $\begin{array}{l}-.00 \\
(0.54)\end{array}$ & $\begin{array}{c}0.000 \\
(0.72)\end{array}$ & $\begin{array}{l}-.000 \\
(2.51)^{*}\end{array}$ & $\begin{array}{l}-.000 \\
(2.70)^{* *}\end{array}$ & $\begin{array}{c}-0.001 \\
(3.08)^{* *}\end{array}$ & $\begin{array}{c}-0.000 \\
(2.02)^{*}\end{array}$ \\
\hline Constant & $\begin{array}{c}4.903 \\
(8.66)^{* *}\end{array}$ & $\begin{array}{l}16.15 \\
(4.59)^{* *}\end{array}$ & $\begin{array}{c}8.288 \\
(14.08)^{* *}\end{array}$ & $\begin{array}{l}21.53 \\
(4.99)^{* * *}\end{array}$ & $\begin{array}{c}5.122 \\
(5.65)^{* *}\end{array}$ & $\begin{array}{l}-.257 \\
(0.03)\end{array}$ \\
\hline Observations & 2,324 & 2,324 & 2,308 & 2,308 & 1,548 & 1,548 \\
\hline $\begin{array}{l}\text { Number of countries } \\
\text { LR chi }{ }^{2}\end{array}$ & $\begin{array}{l}118 \\
1108.44^{* *}\end{array}$ & 118 & $\begin{array}{l}118 \\
767.39^{* *}\end{array}$ & 118 & $\begin{array}{l}84 \\
126.33^{* *}\end{array}$ & 84 \\
\hline R-squared (overall) & & 0.473 & & 0.455 & & 0.210 \\
\hline
\end{tabular}

*significant at $5 \%$ level; ** significant at $1 \%$ level (two-tailed tests).

Absolute value of $z$-statistics in parentheses for random effects regressions; $t$-statistics for fixed effects (based on robust standard errors).

countries in the World Bank sample appear to benefit from a US geopolitical affiliation, as measured by UNGA vote correspondence. Thus, World Bank aid patterns are especially sensitive to the political influence of the United States and its Western allies. This finding also holds in analyses of IMF lending (Thacker, 1999) and fits our assumption that
Bretton Woods institutions are beholden to liberal states.

\section{Robustness Checks and a Replication}

We performed several robustness checks on our results using different combinations of variables and different functional specifications 
of the models. All results from the robustness checks are available from the authors' website.

A first concern is that the random and fixed effects do not sufficiently capture the difference between states that are subjected to UNCHR resolutions. We therefore estimated the model on only those countries that were subject to a UNCHR resolution at some point during our period of analysis. An analysis on this sub-sample should reveal whether countries that experience UNCHR sanctions are rewarded/punished when those sanctions are lifted/imposed. The coefficient on the UNCHR resolution is still statistically and substantively significant for overall multilateral aid $(-.23, p=.004$, in the random effects specification and $-.22, p=.019$, in the fixed effects specification). ${ }^{25}$ The coefficient just fails to reach conventional levels of statistical significance for World Bank aid (-.22, $p=$ .118 , in a two-tailed significance test). We should note, however, that the World Bank sample now includes only 21 countries, and the only variable that reaches the conventional .05 significance level is the war dummy.

An alternative way of addressing this issue is to include a dummy variable in the model that takes the value 1 in the year immediately preceding a UNCHR resolution (if there was no resolution in that year). If our result arises not because of the actual implications of public shaming but rather because of unmodeled country-characteristics, we would expect this variable to have a similar effect to the UNCHR resolution variable (after all, the objective characteristics of countries rarely change much in a year). When incorporated into the model, the coefficient is indistinguishable from zero in all specifications (and positively signed in some specifications). Moreover, the coefficient on the UNCHR resolution remains

\footnotetext{
${ }^{25}$ Note that because of the much smaller sample size in this estimation, we eliminated variables that were insignificant in any specification in Table II from the analysis.
}

negative and significantly different from zero (and from the coefficient on the dummy).

Second, we reran the models for bilateral and multilateral aid on the sample of countries that received World Bank loans because countries receiving World Bank aid differ in important respects from countries that are not eligible for such aid (see Table I). The results confirm that UNCHR resolutions have no effect on bilateral aid receipts. The coefficient on multilateral aid remains substantively $(.23)$ and statistically $(p=.01)$ significant in the random effects model, but is no longer significant in the fixed effects specification on this smaller sample of countries $(p=.15$ in a two-tailed test).

Third, we ran several leaner model specifications to disclose effects that are hidden when including large numbers of variables (Achen, 2005). Our conclusions stood in a model that incorporated only the UN resolution, a lagged dependent variable, orthogonal time trends, and fixed effects control for unit heterogeneity. Given concerns about omitted variable bias, we also estimated models with additional control variables. These included a dummy variable that assumes the value 1 when a state gained independence after 1950 (as countries that were recent colonies are generally expected to obtain higher levels of aid, e.g. Neumayer, 2003c), a variable that takes the value 1 for states that are engaged in a major strategic rivalry (Thompson, 2001), and 0 otherwise (as states in these rivalries may attract aid from donors partial to a side in the dispute), and annual changes in GDP and population as well as squared terms of those variables. The main results are robust to these permutations. ${ }^{26}$

Fourth, we considered the impact on aid allocations of other (weaker) instruments at the UNCHR's disposal, for instance, the commission's use of confidential sessions and

${ }^{26}$ The exception is the fixed effects specification for World Bank aid. This model has a small sample and many variables. As a result, none of the explanatory variables reaches statistical significance. 
advisory opinions (see Lebovic \& Voeten, 2006). We thus employed a dichotomous indicator that combines all UNCHR mechanisms, in place of our UNCHR public resolutions variable, and re-estimated the models in Table II. The new indicator did not reach conventional levels of significance in any specification.

Fifth, we re-estimated all models using the natural log of levels (rather than per capita levels) as the dependent variable. These models included lagged levels of aid, GDP, population and population squared, as well as either random or fixed country-effects. In all models, public UNCHR resolutions had no effect on bilateral aid levels and substantive yet statistically significant effects on multilateral levels of aid as well as World Bank aid.

Sixth, we obtained estimates from Heckman treatment models of the effects on aid when a country is targeted by a public resolution. ${ }^{27}$ With non-random assignment into the treatment and control groups - resolution-receiving and non-resolution-receiving countries, respectively - the treatment is conceivably correlated with the model's residual term. ${ }^{28}$ If so, the estimated coefficient on the treatment variable also captures the effect of omitted or mis-measured variables. A corrective is offered by the Heckman treatment model, which is a member of the class of 'control function' estimators, which seek to correct for non-random assignment. ${ }^{29}$ While treatment regressions are rarely used in political science (for an exception, see Lebovic, 2005), the method is based on the same principle as the Heckman selection model (Heckman, 1979), which is

\footnotetext{
${ }^{27}$ As implemented by the STATA 9.1 treatreg command. ${ }^{28}$ That is, if $\mathrm{U}$ is the disturbance term, $\mathrm{X}$ are the covariates, and $\mathrm{T}$ is the treatment, the treatment model addresses the violation of the assumption that $\mathrm{E}(\mathrm{U} \mid \mathrm{T}, \mathrm{X})=0$.

${ }^{29} \mathrm{An}$ alternative is to use matching approaches. There is a lively debate on the relative merit of matching and control function (e.g. Heckman et al., 1989; LaLonde, 1986). We are not aware, however, of matching models for timeseries-cross-section data.
}

widely employed in studies of arms transfers and aid distributions. The treatment model assumes that certain countries are selected (a binary dependent variable) for exceptional treatment (the first stage) - here, in the form of a public resolution cast against that state in the UNCHR - which leads to penalties at the second stage (a continuous dependent variable) - here, in the form of an average downward change in the country's foreign aid receipts (per capita). If we assume that the error terms in both equations are jointly normally distributed, we can obtain an estimate of the conditional mean of the unobservable variable from the treatment regression and insert this estimate in the outcome (aid level changes) equation.

We estimated a Heckman treatment model by specifying a treatment equation explaining why countries are targeted by UNCHR resolutions - based on Lebovic \& Voeten (2006). Since we cannot reject the null hypothesis that the selection and the outcome equation are independent, we do not report the full results here. ${ }^{30}$ We note, however, that the coefficient on the UNCHR resolution is significant for World Bank aid and falls just short of the .05 significance level for overall multilateral aid $(z=1.91$, which implies significance in a one-tailed test).

Finally, to alleviate any remaining concerns that the results are peculiar to our specific data or model specifications, we replicated a published study on the determinants of multilateral lending (Neumayer, 2003b) and added the UNCHR public resolution variable to models employed in that study. All variables in Neumayer's model are three-year averages for 160 countries between 1983 and 1997. The dependent variable is the share of overall multilateral aid that a country receives. Apart from the independent variables introduced earlier in this article, the analysis includes the number of years (since

\footnotetext{
${ }^{30}$ See the web appendix.
} 
1900) a country was a colony of an OECD country, the minimum distance between a country's capital and New York, Rotterdam, and Tokyo, a country's physical quality of life index (PQLI) score, and a country's level of corruption based on a World Bank and Asian Development Bank indicator (Neumayer, 2003b). The model is estimated using linear regression with robust standard errors clustered on recipient countries.

Table III shows that a UNCHR resolution has a strong and statistically significant effect in almost all model specifications. A UNCHR resolution is estimated, in most model specifications, to coincide with a drop in a country's multilateral aid share of around $40 \%$, a sizeable reduction given that the mean share of aid in the sample is .70 (SD = 1.23). Although the UNCHR resolution is insignificant at the .05 level (in a two-tailed test) in the model that includes all variables, the coefficient is significant to the .05 level in a one-tailed test (appropriate as we have a directional hypothesis). It is important to note that, after controlling for a UNCHR resolution, levels of political freedom are no longer a statistically significant correlate of multilateral aid receipts. This supports our general theoretical proposition that human rights violations affect aid distributions conditionally through the mediating influence of multilateral institutions.

\section{Conclusions}

The statistical analysis provides strong evidence that UNCHR resolutions that condemn a country for poor human rights performance are correlated with large reductions in World Bank and multilateral loan commitments, but have no impact on bilateral aid allocations. Instead, bilateral aid responds mildly to short-term changes in levels of civil rights. These findings have a number of interesting implications for the broader literature in international relations.
First, they shed light on whether public shaming votes in international organizations actually 'matter'. This issue was addressed heretofore with the circumstantial evidence that countries would not exert energy in shaming, and defending against it, if such actions carried no weight. A more convincing case is built around the practical consequences of these sanctioning votes, as they affect donor allocation patterns. We account for this finding, in theoretical terms, by arguing that public votes communicate information about actual norms violations and political preferences within the international community. This information can be useful to other IOs, such as the World Bank, that make consequential decisions under constraints imposed by the preferences of their political principals.

Second, the findings contribute to the large literature on material consequences that governments experience for failing to live up to human rights standards. This literature has focused mostly on bilateral aid or trade relationships and has reduced the role of IOs, at least by implication, to persuading or socializing donors to design their aid policies around the human rights practices of potential recipients. We argue that governments often do not have the incentives to punish norm violators bilaterally, even if these governments would prefer, in the abstract, to punish rights abuses. This gives governments incentives to delegate the enforcement of human rights norms to multilateral institutions, such as the World Bank - this is an important point, because prior research suggests that states might soften their abusive practices with the right foreign incentives, for example, preferential trade agreements (Hafner-Burton, 2005). ${ }^{31}$

\footnotetext{
31 Other research suggests that there is no relationship overall between aid receipts and democratization (Knack, 2004) and changes in aid levels and rights abuses (Regan, 1995). Still, the latter finding (which is most relevant to our analysis) is based on a bivariate analysis of (bilateral) US economic aid for a limited sample of countries and years.
} 
Table III. Replication of Neumayer (2003): Effect of Public Resolutions on Share of Multilateral Aid Flows

\begin{tabular}{|c|c|c|c|c|c|c|c|}
\hline & $I$ & II & III & $I V$ & $V$ & $V I$ & $V I I$ \\
\hline UNCHR Resolution & $\begin{array}{l}-0.395 \\
(3.64)^{* *}\end{array}$ & $\begin{array}{l}-0.362 \\
(3.15)^{* *}\end{array}$ & $\begin{array}{c}-0.422 \\
(3.63)^{* *}\end{array}$ & $\begin{array}{c}-0.372 \\
(2.70)^{* *}\end{array}$ & $\begin{array}{c}-0.411 \\
(3.86)^{* *}\end{array}$ & $\begin{array}{l}-0.346 \\
(2.83)^{* *}\end{array}$ & $\begin{array}{c}-0.261 \\
(1.77)\end{array}$ \\
\hline $\operatorname{Ln}$ (population) & $\begin{array}{l}-1.96 \\
(4.66)^{* *}\end{array}$ & $\begin{array}{l}-2.407 \\
(3.97)^{* *}\end{array}$ & $\begin{array}{l}-2.22 \\
(4.40)^{* *}\end{array}$ & $\begin{array}{l}-2.659 \\
(4.33)^{* *}\end{array}$ & $\begin{array}{l}-2.62 \\
(4.59)^{* *}\end{array}$ & $\begin{array}{l}-3.119 \\
(4.38)^{* *}\end{array}$ & $\begin{array}{l}-3.786 \\
(4.07)^{* *}\end{array}$ \\
\hline $\operatorname{Ln}(\text { population })^{2}$ & $\begin{array}{c}0.077 \\
(5.12)^{* *}\end{array}$ & $\begin{array}{l}0.09 \\
(4.42)^{* *}\end{array}$ & $\begin{array}{c}0.085 \\
(4.84)^{* *}\end{array}$ & $\begin{array}{c}0.098 \\
(4.72)^{* *}\end{array}$ & $\begin{array}{c}0.097 \\
(4.96)^{* *}\end{array}$ & $\begin{array}{c}0.111 \\
(4.71)^{* *}\end{array}$ & $\begin{array}{c}0.131 \\
(4.36)^{* *}\end{array}$ \\
\hline $\operatorname{Ln}(\mathrm{GDP})$ & $\begin{array}{c}-0.302 \\
(6.37)^{* *}\end{array}$ & $\begin{array}{c}-0.336 \\
(5.69)^{* *}\end{array}$ & $\begin{array}{c}-0.341 \\
(5.92)^{* *}\end{array}$ & $\begin{array}{c}-0.406 \\
(6.44)^{* *}\end{array}$ & $\begin{array}{c}-0.255 \\
(3.42)^{* *}\end{array}$ & $\begin{array}{c}-0.391 \\
(5.99)^{* *}\end{array}$ & $\begin{array}{c}-0.389 \\
(3.56)^{* *}\end{array}$ \\
\hline $\operatorname{Ln}$ (colony) & $\begin{array}{l}0.087 \\
(4.95)^{* *}\end{array}$ & $\begin{array}{c}0.092 \\
(4.66)^{* *}\end{array}$ & $\begin{array}{c}0.084 \\
(4.69)^{* *}\end{array}$ & $\begin{array}{l}0.085 \\
(3.95)^{* *}\end{array}$ & $\begin{array}{c}0.075 \\
(4.20)^{* *}\end{array}$ & $\begin{array}{c}0.081 \\
(4.53)^{* *}\end{array}$ & $\begin{array}{c}0.084 \\
(3.72)^{* *}\end{array}$ \\
\hline $\operatorname{Ln}($ distance $)$ & $\begin{array}{c}0.05 \\
(0.64)\end{array}$ & $\begin{array}{c}0.012 \\
(0.14)\end{array}$ & $\begin{array}{c}0.033 \\
(0.41)\end{array}$ & $\begin{array}{l}0.011 \\
(0.1)\end{array}$ & $\begin{array}{c}0.016 \\
(0.19)\end{array}$ & $\begin{array}{c}-0.01 \\
(0.12)\end{array}$ & $\begin{array}{c}0.003 \\
(0.03)\end{array}$ \\
\hline Freedom & $\begin{array}{c}0.028 \\
(1.71)\end{array}$ & $\begin{array}{c}0.038 \\
(1.77)\end{array}$ & $\begin{array}{c}0.028 \\
(1.52)\end{array}$ & $\begin{array}{c}0.04 \\
(1.67)\end{array}$ & $\begin{array}{c}0.032 \\
(1.82)\end{array}$ & $\begin{array}{c}0.033 \\
(1.67)\end{array}$ & $\begin{array}{c}0.045 \\
(1.65)\end{array}$ \\
\hline Year83 & $\begin{array}{c}0.151 \\
(0.97)\end{array}$ & $\begin{array}{c}0.202 \\
(1.07)\end{array}$ & $\begin{array}{c}0.204 \\
(1.09)\end{array}$ & $\begin{array}{c}0.236 \\
(1.05)\end{array}$ & $\begin{array}{c}0.138 \\
(0.86)\end{array}$ & $\begin{array}{c}0.169 \\
(0.87)\end{array}$ & $\begin{array}{c}0.234 \\
(1.00)\end{array}$ \\
\hline Year86 & $\begin{array}{c}0.152 \\
(1.22)\end{array}$ & $\begin{array}{c}0.192 \\
(1.28)\end{array}$ & $\begin{array}{c}0.137 \\
(1.09)\end{array}$ & $\begin{array}{c}0.218 \\
(1.26)\end{array}$ & $\begin{array}{c}0.136 \\
(1.05)\end{array}$ & $\begin{array}{r}0.057 \\
(0.44)\end{array}$ & $\begin{array}{c}0.078 \\
(0.53)\end{array}$ \\
\hline Year89 & $\begin{array}{l}0.098 \\
(0.96)\end{array}$ & $\begin{array}{c}0.126 \\
(1.04)\end{array}$ & $\begin{array}{l}0.113 \\
(1.04)\end{array}$ & $\begin{array}{l}0.125 \\
(0.91)\end{array}$ & $\begin{array}{c}0.094 \\
(0.87)\end{array}$ & $\begin{array}{c}0.091 \\
(0.75)\end{array}$ & $\begin{array}{c}0.122 \\
(0.88)\end{array}$ \\
\hline Year92 & $\begin{array}{c}0.015 \\
(0.18)\end{array}$ & $\begin{array}{c}0.021 \\
(0.21)\end{array}$ & $\begin{array}{c}0.051 \\
(0.53)\end{array}$ & $\begin{array}{c}0.044 \\
(0.37)\end{array}$ & $\begin{array}{c}0.01 \\
(0.11)\end{array}$ & $\begin{array}{r}0.037 \\
(0.37)\end{array}$ & $\begin{array}{c}0.072 \\
(0.63)\end{array}$ \\
\hline PTS & & $\begin{array}{c}0.02 \\
(0.43)\end{array}$ & & & & & $\begin{array}{c}0.061 \\
(1.04)\end{array}$ \\
\hline Corruption (WB) & & & $\begin{array}{c}0.05 \\
(0.92)\end{array}$ & & & & $\begin{array}{l}0.026 \\
(0.35)\end{array}$ \\
\hline Corruption (ICRG) & & & & $\begin{array}{l}0.074 \\
(1.22)\end{array}$ & & & \\
\hline PQLI & & & & & $\begin{array}{c}-0.006 \\
(1.68)\end{array}$ & & $\begin{array}{c}-0.002 \\
(0.39)\end{array}$ \\
\hline Arms imports & & & & & & $\begin{array}{c}0.008 \\
(1.05)\end{array}$ & $\begin{array}{c}0.008 \\
(0.94)\end{array}$ \\
\hline Military expenditure & & & & & & $\begin{array}{c}0.004 \\
(0.81)\end{array}$ & $\begin{array}{c}0.004 \\
(0.79)\end{array}$ \\
\hline Constant & $\begin{array}{l}13.991 \\
(4.97)^{* *}\end{array}$ & $\begin{array}{l}18.187 \\
(3.95)^{* *}\end{array}$ & $\begin{array}{l}16.614 \\
(4.58)^{* *}\end{array}$ & $\begin{array}{l}20.513 \\
(4.55)^{* *}\end{array}$ & $\begin{array}{l}19.754 \\
(4.67)^{* *}\end{array}$ & $\begin{array}{l}24.782 \\
(4.52)^{* *}\end{array}$ & $\begin{array}{l}30.403 \\
(4.19)^{* *}\end{array}$ \\
\hline Observations & 597 & 497 & 543 & 411 & 559 & 481 & 415 \\
\hline R-squared & 0.48 & 0.47 & 0.48 & 0.48 & 0.49 & 0.5 & 0.49 \\
\hline
\end{tabular}

${ }^{*}$ significant at $5 \%$ level; ${ }^{* *}$ significant at $1 \%$ level (two-tailed tests).

Absolute value of $t$-statistics in parentheses

Third, these insights contribute to the literature that asks why governments choose to delegate aid allocation to multilateral institutions. Milner (2006) argues that governments do so because their domestic publics will otherwise doubt that aid has a non-political character. Rodrik (1996) argues that, compared to individual donors, multilateral aid institutions can more credibly demand policy concessions from aid recipients. We provide an additional reason: multilateralism allows states to overcome a collaboration 
dilemma - based in the competitiveness of strategic-based aid allocations - that prevents states from deferring to normative principles when allocating aid.

Our findings are interesting, too, because the World Bank is not generally believed to engage in human rights norms enforcement. Although the World Bank is under considerable pressure from NGOs and governments to take human rights and other social/political factors into consideration when making policy, project, and programmatic decisions, and has adjusted its staff and priorities accordingly, it must also defer to the preferences of its principals. UN resolutions denouncing the human rights performance of an individual government provide a strong signal that project applications by that government can and should be evaluated with admonition. These signals are likely less important for the commission's actions per se than what they represent - a glimpse or culmination of a larger political process through which countries are marginalized in international politics. By the time the UNCHR acts decisively against alleged violators, they could be well along in the process of global shaming. Notable, for instance, is that the commission contended with some cases (e.g. Israel) because they were symbolic cases and acted, then, in response to world opinion as much as to reinforce that opinion. Regardless, the implication remains that, in an important sense, multilateral institutions bolstered their interventions by ensuring that they had adequate international political support and, thus, that the World Bank acted as a selective enforcer of international human rights norms.

\section{References}

Abbott, Kenneth \& Duncan Snidal, 1998. 'Why States Act Through Formal International Organizations', Journal of Conflict Resolution 42(1): 3-32.
Abrams, Burton A. \& Kenneth A. Lewis, 1993. 'Human Rights and the Distribution of US Foreign Aid', Public Choice 77(4): 815-821.

Achen, Christopher H., 2005. 'Let's Put GarbageCan Regressions and Garbage-Can Probits Where They Belong', Conflict Management and Peace Science 22(4): 327-339.

Alesina, Alberto \& David Dollar, 2000. 'Who Gives Foreign Aid to Whom and Why?', Journal of Economic Growth 5(1): 33-63.

Alesina, Alberto \& Beatrice Weder, 2002. 'Do Corrupt Governments Receive Less Foreign Aid?', American Economic Review 92(4): 1126-1137.

Andersen, Thomas Barnebeck; Henrik Hansen \& Thomas Markussen, 2006. 'US Politics and World Bank Lending', Journal of Development Studies 42(5): 772-794.

Apodaca, Clair \& Michael Stohl, 1999. 'United States Human Rights Policy and Foreign Assistance', International Studies Quarterly 43(1): 185-198.

Beck, Nathaniel \& Jonathan N. Katz, 2007. 'Random Coefficient Models for TimeSeries-Cross-Section Data: Monte Carlo Experiments', Political Analysis 15(2): 182-195.

Becker, Gary S., 1994. Human Capital. Chicago, IL: University of Chicago Press.

Bennett, D. Scott \& Allan Stam, 2000. 'EUGene: A Conceptual Manual', International Interactions 26(2): 179-204.

Bradlow, Daniel D., 1996. 'The World Bank, the IMF, and Human Rights', Transnational Law and Contemporary Problems 6(1): 47-90.

Carey, Sabine C., 2007. 'European Aid: Human Rights Versus Bureaucratic Inertia?', Journal of Peace Research 44(4): 447-464.

Carleton, David \& Michael Stohl, 1987. 'The Role of Human Rights in US Foreign Assistance Policy: A Critique and Reappraisal', American Journal of Political Science 31(4): 1002-1018.

Cassidy, John, 2007. 'The Next Crusade: Paul Wolfowitz at the World Bank', New Yorker 9 April.

Cingranelli, David L. \& Thomas E. Pasquarello, 1985. 'Human Rights Practices and the Distribution of U.S. Foreign Aid to Latin American Countries', American Journal of Political Science 29(3): 539-563. 
Dañino, Roberto, 2004. 'The Legal Aspects of the World Bank's Work on Human Rights', in Philip Alston \& Mary Robinson, eds, Human Rights and Development: Towards Mutual Reinforcement. Oxford: Oxford University Press (509-520).

Donnelly, Jack, 1988. 'Human Rights at the United Nations 1955-1985: The Question of Bias', International Studies Quarterly 32(3): 275-303.

Gibney, Mark \& Matthew Dalton, 1996. 'The Political Terror Scale', Policy Studies and Developing Nations 4: 73-84.

Gleditsch, Nils Petter; Peter Wallensteen, Mikael Eriksson, Margareta Sollenberg \& Håvard Strand, 2002. 'Armed Conflict 1946-2001: A New Dataset', Journal of Peace Research 39(5): 615-637.

Hafner-Burton, Emilie, 2005. 'Trading Human Rights: How Preferential Trade Agreements Influence Government Repression', International Organization 59(3): 593-629.

Hafner-Burton, Emilie \& Kiyoteru Tsutsui, 2005. 'Human Rights Practices in a Globalizing World: The Paradox of Empty Promises', American Journal of Sociology 110(5): 1373-1411.

Hafner-Burton, Emilie \& Kiyoteru Tsutsui, 2007. 'Justice Lost! The Failure of International Human Rights Law to Matter Where Needed Most', Journal of Peace Research 44(4): 407-425.

Hathaway, Oona A., 2002. 'Do Human Rights Treaties Make a Difference?', Yale Law Journal 111(8): 1935-2042.

Heckman, J., 1979. 'Sample Selection Bias as a Specification Error', Econometrica 47(1): 153-161.

Heckman, James J.; Paul W. Holland, V. Joseph Hotz \& Robert Moffitt, 1989. 'Choosing Among Alternative Nonexperimental Methods for Estimating the Impact of Social Programs: The Case of Manpower Training', Journal of the American Statistical Association 84(408): 878-880.

Kaufmann, Daniel, 2005. 'Human Rights and Governance: The Empirical Challenge', in Philip Alston \& Mary Robinson, eds, Human Rights and Development: Towards Mutual
Reinforcement. Oxford: Oxford University Press (352-402).

Keohane, Robert O. \& Lisa L. Martin, 1995. 'The Promise of Institutionalist Theory', International Security 20(1): 39-51.

Knack, Stephen, 2004. 'Does Foreign Aid Promote Democracy?', International Studies Quarterly 48(1): 251-266.

LaLonde, R., 1986. 'Evaluating the Econometric Evaluations of Training Programs with Experimental Data, American Economic Review 76(4): 604-620.

Lebovic, James H., 1988. 'National Interests and US Foreign Aid: The Carter and Reagan Years', Journal of Peace Research 25(2): 115-135.

Lebovic, James H., 2005. 'Donor Positioning: Development Assistance from the U.S., Japan, France, Germany, and Britain', Political Research Quarterly 58(1): 119-126.

Lebovic, James H. \& Erik Voeten, 2006. 'The Politics of Shame: The Condemnation of Country Human Rights Practices in the UNCHR', International Studies Quarterly 50(4): 861-888.

Lijphart, Arend, 1963. 'The Analysis of Bloc Voting in the General Assembly: A Critique and a Proposal', American Political Science Review 57(4): 902-917.

Meernik, James; Eric L. Krueger \& Steven C. Poe, 1998. 'Testing Models of U.S. Foreign Policy: Foreign Aid During and After the Cold War', Journal of Politics 60(1): 63-85.

Milner, Helen, 2006. 'Why Multilateralism? Foreign Aid and Domestic Principal-Agent Problems', in Darren G. Hawkins, David A. Lake, Daniel L. Nielson \& Michael J. Tierney, eds, Delegation and Agency in International Organizations. New York: Cambridge University Press (107-139).

Neumayer, Eric, 2003a. 'Do Human Rights Matter in Bilateral Aid Allocation? A Quantitative Analysis of 21 Donor Countries', Social Science Quarterly 84(3): 650-666.

Neumayer, Eric, 2003b. 'The Determinants of Aid Allocation by Regional Multilateral Development Banks and United Nations Agencies, International Studies Quarterly 47(1): 101-122. 
Neumayer, Eric, 2003c. The Pattern of Aid Giving: The Impact of Good Governance on Development Finance. London: Routledge.

Neumayer, Eric, 2003d. 'Is Respect for Human Rights Rewarded? An Analysis of Total Bilateral and Multilateral Aid Flows', Human Rights Quarterly 25(2): 510-527.

North, Douglass, 1990. Institutions, Institutional Change, and Economic Performance. New York: Cambridge University Press.

Poe, Steven C., 1992. 'Human Rights and Economic Aid Allocation Under Ronald Reagan and Jimmy Carter', American Journal of Political Science 36(1): 147-167.

Regan, Patrick M., 1995. 'U.S. Economic Aid and Political Repression: An Empirical Evaluation of U.S. Foreign Policy', Political Research Quarterly 48(3): 613-628.

Risse, Thomas \& Kathryn Sikkink, 1999. 'The Socialization of International Human Rights Norms into Domestic Practices: Introduction', in Thomas Risse, Stephen C. Ropp \& Kathryn Sikkink, eds, The Power of Human Rights. New York: Cambridge University Press (1-38).

Rodrik, Dani, 1996. 'Why Is There Multilateral Lending?', in M. Bruno \& B. Pleskovic, eds, Annual World Bank Conference on Development Economics, 1995. Washington, DC: International Monetary Fund.

Saiegh, Sebastian M., 2005. 'Do Countries Have a "Democratic Advantage"? Political Institutions, Multilateral Agencies, and Sovereign Borrowing', Comparative Political Studies 38(4): 366-387.

Schraeder, Peter J.; Steven W. Hook \& Bruce Taylor, 1998. 'Clarifying the Foreign Aid Puzzle: A Comparison of American, Japanese, French, and Swedish Aid Flows', World Politics 50(2): 294-323.

Skogly, Sigrun I., 2001. Human Rights Obligations of the World Bank and the IMF. London: Cavendish.

Thacker, Strom Cronan, 1999. 'The High Politics of IMF Lending', World Politics 52(1): 38-75.

Thompson, William R., 2001. 'Identifying Rivals and Rivalries in World Politics', International Studies Quarterly 45(4): 557-586.
Torchia, Christopher, 2006. 'IMF-World Bank Annual Meeting End', Associated Press Online 20 September, 8:46 AM.

Voeten, Erik, 2000. 'Clashes in the Assembly', International Organization 54(2): 185-215.

Voeten, Erik, 2005. 'The Political Origins of the United Nations Security Council's Ability to Legitimize the Use of Force', International Organization 59(3): 527-557.

Weingast, Barry R., 1997. 'The Political Foundations of Democracy and the Rule of the Law', American Political Science Review 91(2): 245-263.

Weisman, Steven R., 2006. 'Wolfowitz Corruption Drive Rattles World Bankers', New York Times 14 September: C1.

Western, Bruce, 1998. 'Causal Heterogeneity in Comparative Research: A Bayesian Hierarchical Modeling Approach', American Journal of Political Science 42(4): 1233-1259.

Wolfowitz, Paul 2006. 'Good Governance and Development: A Time for Action', Jakarta, Indonesia, 11 April (http://go.worldbank.org/ HKMUDLHE10).

World Bank, 1998. Assessing Aid. Washington, DC: World Bank Group.

JAMES H. LEBOVIC, b. 1952, $\mathrm{PhD}$ in International Relations (University of Southern California, 1981); Associate Professor of Political Science and International Affairs, George Washington University (1982- ). Research interests include defense spending, policy, and strategy.

ERIK VOETEN, b. 1972, PhD in Political Science (Princeton University, 2001); Assistant Professor of Political Science and International Affairs, George Washington University (2002-07); Peter F. Krogh Assistant Professor of Geopolitics and Global Justice, Georgetown University (2007- ). Research interests include international organizations and statistical methods. 